www.volsu.ru

DOI: http://doi.org/10.15688/nav.jvolsu.2017.1.9

UDC 903' 1(470):726

LBC 63.442.7(235.7)-427

\title{
SARMATIAN BURIALS FROM THE BARROW 1 OF BURIAL MOUND NEAR KULESHOVKA VILLAGE (EXCAVATIONS OF 1982)
}

\author{
Vyacheslav P. Glebov \\ Archaeological Research Bureau, Rostov-on-Don, Russian Federation
}

\begin{abstract}
The article is devoted to the publication of series of five early Sarmatian burials in the barrow 1 of the burial mound, which is located to the West of Kuleshovka village of Azov district in the Rostov region. Burials were made inside of the barrow of the Bronze Age and formed a rough row in the west-east direction. The 10th burial destroyed the previous 9 th burial. The burials were constructed inside of the undercuts and rectangular pits, in one case - in the double-chamber undercut. All the buried were stretched out on their back and oriented to the southern sector. The burial equipment is represented by swords, arrows, mirrors, beads and various ceramics. Most of the burials might form a family-clan burial mound. The analysis of the burial equipment shows that most of the burials belong to the early stage of the Early Sarmatian culture of the Lower Don region and dates from the $2^{\text {nd }}$ century BC, perhaps, the second-third quarter of the century. This date is set by a sword with a sickle-shaped head, arrow heads with slightly profiled three-bladed heads and long petioles, the "megarian" bowl (burial 17), the mirror with a large diameter by the edge of the roller (burial 10), the red-lacquer kanfar and Bosporian jug (burial 29). The burial 24, which is located on the edge of the western row, might be an exception; because it has later equipment consisted of a sword with a ring-shaped head of later time and arrow heads with short petioles.
\end{abstract}

Key words: Early Sarmatian culture, family-clan burial mound, chronological indicators, red-lacquer kanfar, "megarian" bowl.

Citation. Glebov V.P., 2017. Sarmatian Burials from the Barrow 1 of Burial Mound near Kuleshovka Village (Excavations of 1982). The Lower Volga Archaeological Bulletin, vol. 16, no. 1, pp. 143-161. (in Russian).

УДК 903'1(470):726

ББК 63.442.7(235.7)-427

\section{САРМАТСКИЕ ПОГРЕБЕНИЯ ИЗ КУРГАНА 1 МОГИЛЬНИКА У с. КУЛЕШОВКА (РАСКОПКИ 1982 Г.)}

\author{
Вячеслав Петрович Глебов \\ Археологическое научно-исследовательское бюро, г. Ростов-на-Дону, Российская Федерация
}

\begin{abstract}
Аннотация. Статья посвящена публикации серии из пяти раннесарматских погребений в кургане 1 могильника, находящегося к западу от с. Кулешовка Азовского района Ростовской области. Погребения были впущены в курган эпохи бронзы, составляли неровный ряд в направлении 3-В, при этом погребение 10 разрушило более раннее погребение 9. Захоронения были совершены в подбоях и прямоугольных ямах, в одном случае - в двухкамерном подбое. Все погребенные были уложены вытянуто на спине, ориентированы в южный сектор. Инвентарь захоронений погребений представлен мечами, стрелами, зеркалами, бусами, различной керамической посудой. Большинство погребений, вероятно, составляют семейно-родовой могильник. Анализ погребального инвентаря показывает, что большая часть захоронений относится к раннему этапу раннесарматской культуры Нижнего Подонья и датируется II в. до н.э., скорее всего, второй - третьей $\overrightarrow{\widetilde{\sim}}$ четвертью столетия. Такая дата устанавливается по мечу с серповидным навершием, наконечникам стрел со слабопрофилированными трехлопастными головками и длинными черешками, «мегарской» чаше (погребение 17), зеркалу большого диаметра с валиком по краю (погребение 10), краснолаковому канфару и бос: порскому кувшину (погребение 29). Исключение, возможно, составляет крайнее западное в ряду погребение 24, сопровождавшееся более поздним инвентарем - мечом с кольцевидным навершием позднего облика, наконечниками стрел с короткими черешками.
\end{abstract}


Ключевые слова: раннесарматская культура, семейно-родовой могильник, хроноиндикаторы, краснолаковый канфар, «мегарская» чаша.

Цитирование. Глебов В. П., 2017. Сарматские погребения из кургана 1 могильника у с. Кулешовка (раскопки 1982 г.) // Нижневолжский археологический вестник. Т. 16, №1.С.143-161.

В 1982 г. Приморским археологическим отрядом Азовского краеведческого музея под руководством Е.И. Беспалого были проведены раскопки кургана 1 могильника, находящегося к западу от с. Кулешовка Азовского района Ростовской области. Насыпь кургана была частично разрушена глиняным карьером кирпичного завода и окопами времени Великой Отечественной войны, к моменту раскопок была сильно распахана. Высота кургана составляла около 0,5 м, насыпь была овальной в плане формы, вытянута в направлении С-Ю, ее размеры - приблизительно $27 \times 32$ м.

Курган был сооружен в эпоху ранней бронзы, содержал 37 разновременных погребений и 14 ям (рис. 1). В настоящей публикации рассматриваются впускные захоронения раннесарматской культуры, исследованные в этом кургане - погребения 9, 10, 17, 24, 29.

Погребение 9 (рис. 2,2-4). Находилось в 2,3 м к 3СЗ от $R_{0}{ }^{1}$, глубина - 1,5 м.

Погребальное сооружение было подбойной конструкции. Входной колодец, прослеженный лишь частично, находился с северо-западной стороны от погребальной камеры. В камеру вела высокая, слегка наклонная ступенька. Погребальная камера подовальной в плане формы была ориентирована длинной осью в направлении ССВ-ЮЮЗ, размеры ее составляли $0,9 \times 1,8 \mathrm{M}$.

Погребение было разрушено в древности, вероятно, при совершении погребения 10. В заполнении могилы были встречены предметы погребального инвентаря, а также кости детей 2-3 и 10-12 лет (определение Е.И. Беспалого) ${ }^{2}$, причем кости стоп, кистей и некоторых суставных соединений находились в сочленении. На дне камеры были прослежены участки коричневого тлена и мелкие комочки ярко-оранжевой краски (реальгар?).

Погребальный инвентарь:

1. Стеклянные бусы и бисер:

- треугольные уплощенные подвески, спаянные из ярко-желтого, светло-синего и темно-синего стекла с узкими прослойками белого цвета (4 шт.) (рис. 2,3a);

- стрелковидные подвески, спаянные из ярко-желтого и синего стекла с узкими прослойками белого цвета (3 шт.) (рис. 2,3б);

- каплевидные подвески, спаянные из ярко-желтого и синего стекла с узкими прослойками белого цвета (4 шт.) (рис. 2,3в);

- каплевидная подвеска из полупрозрачного синего стекла (рис. 2,32) ;

- цилиндрическая бусина со скошенными торцами из желто-коричневого стекла (рис. 2,3d);

- коротко-цилиндрические бусы с двумя поперечными рядами мелких бугорков (8 шт.) (рис. 2,3e);

- округлые и бочковидные поперечносжатые бусы из синего и желто-коричневого полупрозрачного стекла (15 шт.) (рис. 2,3ж);

- округло-бочковидная бусина с крупными разноцветными (сине-зелеными с узкими белыми прослойками) глазками (рис. 2,33);

- округлые и бочковидные поперечносжатые ребристые бусы из зеленого полупрозрачного стекла (14 шт.) (рис. 2,3u);

- бусы из бесцветного полупрозрачного стекла с внутренней позолотой различной формы: округлые, бочковидные поперечносжатые, вытянутые подцилиндрические (11 шт.) (рис. 2,3к);

- бисер из белого и синего непрозрачного стекла (более 200 шт.) (рис. 2,3л).

2. Небольшой лепной сосуд (рис. 2,4). Тулово биконической формы, горло низкое, венчик отогнут, дно слегка выпуклое. Поверхность со следами затирания, темно-серого цвета, нижняя часть тулова закопчена. Тесто грубое, рыхловатое, черепок в изломе черного цвета. Примеси в тесте: песок, шамот, известь (?). Размеры: высота - 6,5 см, диаметр $-8,5$ см.

3. Фрагмент расслоившейся железной пластины.

4. Небольшие обточенные кусочки мела (2 шт.). 
Погребение 10 (рис. 3,1-3). Находилось в 3,5 м к северо-западу от $R_{0}$, глубина 1,64 м. Могила полностью разрушила погребение 4 (возможно, также раннесарматского времени) и частично перекрыла погребение 9. Вероятно, погребение 9 было ограблено при совершении погребения 10.

Погребальное сооружение представляло собой узкую яму подпрямоугольной в плане формы со скругленными углами, размерами $1 \times 2,4$ м, ориентированную длинной осью в направлении ССЗ-ЮЮВ. На дне ямы был прослежен слой (подсыпка?) рыхлого мешаного грунта с включением детских костей, бус и фрагментов подстилки из погребения 9. Мощность этого слоя была различной: в южной и северной части ямы $-0,35$ м, в центральной части ямы $-0,1$ м. В заполнении в северной части могильной ямы были встречены разрозненные кости ног взрослого человека, вероятно, происходящие из разрушенного погребения 4.

На подсыпке лежал костяк взрослой женщины (определение Е.И. Беспалого), располагавшийся вытянуто на спине с ЮЮВ ориентировкой. Правая рука, согнутая в локте, была уложена поверх грудной клетки, запястьем на левой ключице. Левая рука в древности была отчленена от тела погребенной в плечевом суставе и уложена слева вдоль костяка, плечевым суставом в сторону таза. Череп с нижней челюстью находился в юго-восточном углу в заполнении могилы (15-20 cм от уровня подсыпки) - возможно, был перемещен норой, но не исключено, что череп, как и левая рука, был отчленен от тела. В заполнении могилы и на дне под костяком встречались древесные угольки.

Погребальный инвентарь:

\section{1. Стеклянные бусы:}

У левой голени погребенной, от середины берцовых костей до стопы, было расчищено скопление бус:

- округлые и бочковидные бусы из синего полупрозрачного стекла (27 шт.) (рис. 3,2a);

- бочковидные поперечносжатые бусы из бесцветного полупрозрачного стекла с внутренней позолотой (15 шт.) (рис. 3,26);

- уплощенно-биконические бусы из синего и желтого полупрозрачного стекла (9 шт.) (рис. 3,26).
Под правой голенью погребенной, у стопы, также были встречены округлые и бочковидные бусы из синего полупрозрачного стекла (7 шт.), аналогичные найденным у левой ноги.

2. Фрагмент бронзового зеркала с валиком по краю (рис. 3,3) - под костяком в районе правой лопатки. Реконструируемый диаметр диска около $18 \mathrm{~cm}$, толщина диска $0,3 \mathrm{~cm}$, ширина валика 1,4 см, толщина 0,5 см. Края изломов сглажены.

Помимо этого, в заполнении могилы были встречены находки, которые могут происходить из погребений 9 или 4, хотя нельзя исключить и принадлежность их к погребению 10: фрагмент стенки амфоры, фрагменты лепного сосуда, обломок раковины unio, мелкий обломок песчаника.

Погребение 17 (рис. 4,1-6). Находилось в 5,5 м к западу от $R_{0}$, глубина $-2,22$ м.

Погребальное сооружение было подбойной конструкции. Входной колодец подпрямоугольной в плане формы был ориентирован длинной осью в направлении СЗ-ЮВ, размеры его составляли $0,75 \times 1,9$ м. Дно колодца плавно понижалось к северо-восточной длинной стенке, под которой находился вход в камеру. Погребальная камера подпрямоугольной в плане формы была ориентирована параллельно колодцу, размеры ее - 1,07 × 2,1 м.

На дне камеры лежал костяк погребенного ${ }^{3}$, располагавшийся вытянуто на спине с юго-восточной ориентировкой. Череп был слегка развернут вправо, руки и ноги вытянуты. Под костяком были зафиксированы следы «тростниковой подстилки».

\section{Погребальный инвентарь:}

1. Фрагменты бронзового зеркала (2 шт.) (рис. 4,3) - находились рядом: один фрагмент между грудной клеткой и правым локтем, второй - под правым локтем. Фрагменты, вероятно, принадлежат одному зеркалу, хотя и не стыкуются. Зеркало представляло собой плоский диск с несколько утолщенным и скругленным краем, очевидно, без ручки. Реконструируемый диаметр диска - около 6-6,5 см, толщина диска в центре - 0,150,2 см, у края - 0,3 см.

2. Железный меч (рис. 4,5) - справа вдоль таза и бедра, рукоять находилась под предплечьем правой руки, конец клинка был 
отломлен (в древности?) и смещен на несколько сантиметров. Меч с серповидным навершием, без перекрестья, общая длина меча $-43 \mathrm{~cm}$, длина рукояти - $10 \mathrm{~cm}$, клинка -33 см.

3. Железные наконечники стрел (около 30 шт.) (рис. 4,2) - располагались компактной группой на левой берцовой кости, остриями к юго-востоку (в сторону таза). Наконечники трехлопастные, черешковые, головки треугольной формы, лопасти намечены слабо, черешки длинные, четырехгранные, подквадратные в сечении, прослежены остатки древков. Размеры наконечников: высота головки - 3-3,5 см, ширина основания - 1,31,4 см, длина черешков - 5-9 см.

4. Костяная «проколка» (рис. 4,4) между берцовыми костями, рядом с наконечниками стрел (вероятно, находилась в колчане). «Проколка» тщательно отполирована, имеет Г-образную головку со сквозным отверстием. Длина «проколки» 20,7 см.

5. «Мегарская» чаша (рис. 4,6 ) - стояла между стоп. Тулово чаши полусферической формы, бортик слегка наклонен внутрь, венчик скруглен, поддон низкий кольцевой, дно вогнуто. Чаша орнаментирована в верхней части пояском из восьмилепестковых розеток, по тулову - стилизованными узкими листьями, разделенными линиями из рельефных точек. Рельеф орнамента невысокий. Поверхность чаши покрыта матовым темным лаком коричневого цвета. Тесто светло-коричневого цвета, плотное, тонко отмученное, примеси: мельчайшие частицы слюды, редкие включения мелких белых неорганических частиц (известь?). Чаша в древности была разбита, имеет следы ремонта - три пары отверстий на тулове. Размеры чаши: высота $-6,3$ см, диаметр - 12,1 см.

Погребение 24 (рис. 3,4-9). Находилось в 10 м к 3СЗ от $R_{0}$, глубина $-1,84$ м.

Погребальное сооружение было подбойной конструкции. Входной колодец подпрямоугольной в плане формы со скругленными углами был ориентирован длинной осью в направлении ССЗ-ЮЮВ, его размеры: длина 2,15 м, ширина (до ступеньки) 0,48-0,55 м. Погребальная камера находилась под длинной восточной стенкой колодца, в камеру вела невысокая (4 см) ступенька. Камера подпря- моугольной в плане формы с сильно скругленным северо-восточным углом была ориентирована параллельно колодцу, размеры ее составляли $0,45-0,58 \times 2 \mathrm{M}$.

На дне камеры лежал костяк взрослого человека (определение Е.И. Беспалого), располагавшийся вытянуто на спине с ЮЮВ ориентировкой. Череп был полуразвернут вправо, левая рука слегка отведена в сторону.

Напутственная пища: кости барана передняя нога с лопаткой в сопровождении фрагмента ножа - были найдены у левой стопы погребенного.

Погребальный инвентарь:

1. Железный меч (рис. 3,9) - лежал справа вдоль таза и бедра, рукоять частично находилась под предплечьем правой руки. Меч с кольцевидным навершием и прямым перекрестьем, общая длина меча - 51 см, длина рукояти -13 см, клинка -38 см.

2. Железные наконечники стрел (около 30 шт.) (рис. 3,5) - располагались компактной группой у правого предплечья, остриями к ЮЮВ (в сторону черепа). Наконечники трехлопастные, черешковые, головки треугольные или сводчатые, лопасти выделены, черешки короткие, округлые в сечении, с остатками древков. Размеры наконечников: высота головки $-2,8-3,2 \mathrm{~cm}$, ширина основания $0,8-1,1$ см, длина черешков - 1,3-1,5 см.

3. Фрагменты железного предмета (пряжки?) неясной конструкции (рис. 3,8 ) на левом крыле таза.

4. Фрагмент лезвия железного ножа (рис. 3,7)-у левой стопы погребенного, рядом с костями барана. Длина сохранившейся части лезвия около $3 \mathrm{~cm}$.

5. Бронзовые заклепки (4 шт. $\left.{ }^{4}\right)$ (рис. 3,6) - слева от погребенного, между кистью руки и бедром. Высота заклепок - около 0,4 см, диаметр $-0,25$ см.

Погребение 29 (рис. 5 и 6). Находилось в 6 м к северо-востоку от $R_{0}$, глубина $-2,04$ м.

Погребальное сооружение представляло собой двухкамерный подбой. Входной колодец подпрямоугольной в плане формы со скругленными углами был ориентирован длинной осью в направлении ССЗ-ЮЮВ, размеры его составляли $1,2 \times 2,27$ м. В заполнении колодца по всей площади встречались «в боль- 
шом количестве разрубленные в древности кости теленка и двух особей барана», а также «остатки горелого камыша». Помимо этого, в заполнении колодца были встречены фрагмент раковины unio и стеклянные бусы, вероятно, вынесенные норами из камер: крупная подцилиндрическая бусина из непрозрачного зеленого стекла (рис. 5,2a), округлые и бочковидные поперечносжатые бусы из бесцветного полупрозрачного стекла с внутренней позолотой (17 шт.) (рис. 5,26). Под восточной стенкой находился вход в камеру А, под западной - вход в камеру Б, из колодца в камеры вели невысокие (8-12 см) ступеньки. Обе камеры были ориентированы параллельно колодцу.

Погребальная камера А была подпрямоугольной в плане формы со скругленными углами, размеры: $0,9 \times 2,05$ м, глубина $-2,04$ м. В заполнении у входа были встречены фрагменты древесины - остатки заклада.

На дне камеры лежал костяк женщины 40-45 лет (определение Е.Ф. Батиевой), располагавшийся вытянуто на спине с ЮЮВ ориентировкой. Руки были полусогнуты в локтях, скрещены запястьями в области таза. Под костяком и по большей части площади дна был прослежен черный органический тлен.

Погребальный инвентарь:

1. Миниатюрный кружальный (?) сосудик плохого обжига (рис. 6,4 ) - у правого плеча погребенной. Тулово подовальной формы приземистых пропорций, переходит без горла в резко отогнутый уплощенный венчик, дно на небольшом ложном поддоне. По верхней части тулова проходит горизонтальная прочерченная линия. Поверхность сосуда серокоричневого цвета, имеет следы лощения. Тесто тонко отмучено, черепок в изломе коричневого цвета. Сосуд едва обожжен, в результате чего тулово несколько деформировалось. Размеры: высота - 6,3 см, диаметр $8,6 \mathrm{~cm}$.

2. Стеклянные бусы (рис. 5,3) - большое скопление бус было расчищено на участке дна размерами около $35 \times 10$ см вдоль правого предплечья от плечевого сустава до локтя. Бусы округлые и бочковидные поперечносжатые из бесцветного полупрозрачного стекла с внутренней позолотой (около 280 шт.).
3. Бронзовое зеркало (рис. 5,8) - у правой плечевой кости погребенной, среди скопления бус. Зеркало представляло собой плоский диск со скошенным краем, без ручки. Диаметр диска - 7,3 см, толщина диска - 0,2$0,25 \mathrm{~cm}$.

4. Кружальная оранжевоглиняная миска (рис. 6,2) - у левого тазобедренного сустава. Миска со слегка выпуклыми стенками, загнутым внутрь бортиком и ложным поддоном, декорирована по бортику волнистым орнаментом, состоящим из двух прочерченных линий. Поверхность оранжевого цвета, тщательно заглажена. Тесто тонко отмучено, черепок в изломе оранжевого цвета. Примеси в тесте: слюда, известь (?). Размеры: высота $-8,5$ см, диаметр - 22,9 см.

5. Краснолаковый канфар (рис. 6,1 )у правой голени погребенной. Тулово канфара яйцевидно-биконической формы, поддон высокий, венчик отогнут, петельчатые ручки с налепами. Лак матовый со слабым блеском, красновато-коричневый, местами цвет его переходит в черный. Орнамент представлял собой процарапанные по верхней части тулова закрученные стебли; возможно, они дополнялись несохранившимися листьями или гирляндами, нанесенными жидкой глиной или краской поверх лака. Тесто розово-оранжевого цвета, тонко отмучено, примеси: мельчайшие частицы слюды, редкие включения мелких белых неорганических частиц (известь?). Размеры: высота - 10,7 см, диаметр - 13 см.

6. Раковина rapana (рис. 5,7 ) - в заполнении камеры (10 см от дна) в районе стоп погребенной.

Погребальная камера Б была подпрямоугольной в плане формы со скругленными углами, размеры: 0,95 × 2,23 м, глубина $-1,96$ м. В заполнении у входа были встречены фрагменты камышового тлена - остатки заклада.

На дне камеры лежал костяк женщины 25-30 лет (определение Е.Ф. Батиевой), располагавшийся вытянуто на спине с ЮЮВ ориентировкой. Череп был полуразвернут вправо. Правая рука была вытянута вдоль туловища, левая полусогнута в локте, кисть ее находилась на тазе. Правая нога была вытянута, левая полусогнута коленом вправо. Под костяком и по большей части площади дна был прослежен органический тлен. 
Погребальный инвентарь:

1. Фрагменты железного ножа (рис. 5,6) - в заполнении центральной части камеры (12-15 см от дна). Длина сохранившейся части ножа около $10 \mathrm{~cm}$.

2. Фрагменты бронзового зеркала (рис. 5,9) - в заполнении над коленными суставами, выше уровня костей на 15 см. Фрагменты собрались в почти целый диск. Зеркало представляло собой плоский диск со скошенным краем, без ручки. Диаметр диска около $8 \mathrm{~cm}$, толщина диска $-0,2-0,25$ см.

3. Стеклянные бусы - были встречены вокруг черепа, а также в заполнении камеры:

- округлые и бочковидные поперечносжатые из бесцветного полупрозрачного стекла с внутренней позолотой (27 шт.) (рис. 5,4a);

- уплощенно-биконическая ребристая бусина из желтого непрозрачного стекла (рис. 5,4б).

4. Золотая бляшка (рис. 5,5) - между стопами погребенной. Форма бляшки близка к полусферической, по краям имеются два отверстия для пришивания. Диаметр бляшки 0,6 см, высота - 0,4 см.

5. Кружальный оранжевоглиняный кувшин (рис. 6,3) - лежал на боку вдоль правой голени и стопы, устьем к северу. Кувшин крупный, с высоким горлом, отогнутым венчиком, низким кольцевым поддоном, вертикальной профилированной ручкой. Поверхность оранжевого цвета, довольно тщательно заглажена. Кувшин декорирован по горлу рядом из пяти узких горизонтальных кольцевых желобков. Тесто тонко отмучено, черепок в изломе оранжевого цвета. Примеси в тесте: слюда, известь (?), коричневые частицы. Часть горла с венчиком была отбита в древности, сосуд имеет следы ремонта - два просверленных отверстия на горле. Размеры кувшина: высота - 28,4 см, диаметр - 20 см.

Раннесарматские погребения в кургане 1 могильника Кулешовка сконцентрированы в центральной части насыпи и, как будто, составляют неровный ряд в направлении 3-В (рис. 2,1).

Для раннесарматской культуры характерны группы из нескольких погребений, впущенных в курганы более ранних эпох, часто с рядным или кольцевым (полукольцевым) располо- жением могил. Обычно такие серии погребений трактуются как семейно-родовые кладбища и считаются хронологически компактными [Смирнов, 1960, с. 258; Скрипкин, 1990, с. 190; Мордвинцева, 1993, с. 31-34; Сергацков, 2000 , с. 200; Власкин, 2000, с. 14-15; Железчиков, Клепиков, Сергацков, 2006, с. 40-41; Глебов, 2011, с. 34]. Однако рядность сарматских погребений в кулешовском кургане выражена неотчетливо, к тому же погребение 9 было перекрыто погребением 10 и, вероятно, разрушено (ограблено?) при совершении последнего. Подобные случаи, когда одно-два погребения (очевидно, наиболее поздние) выбивались из ряда или кольца, иногда перекрывая более ранние захоронения, известны: Ясырев III, курган 1, Красногоровка III, курган 4, Подгорненский IV, курганы 5, 30, Св. Колодезь III, курган 1. Таким образом, единство группы сарматских погребений из кургана 1 , на наш взгляд, может быть поставлено под сомнение. Для прояснения этого вопроса рассмотрим подробнее хронологию некоторых вещей из исследованных в кургане сарматских погребений.

Меч из погребения 17 (рис. 4,5). Мечи с серповидным навершием появляются у сарматов в IV в. до н.э., позже - в III-II вв. до н.э. - становятся наиболее популярным в сарматской среде клинковым оружием [Смирнов, 1961 , с. 27 ; Мошкова, 1963, с. 34; Клепиков, 2002, с. 29-30; Васильев, 2001, с. 45-49; Глебов, 2007, с. 92-94]. На завершающем этапе раннесарматской культуры такие мечи встречаются уже относительно редко [Сергацков, 1995 , с. $151,154-157$, рис. 3,1,6; Власкин, 2000, c. $12,17-19$, рис. 4,1], в комплексах последующих сарматских эпох известны лишь единичные находки кинжалов с серповидным навершием [Очир-Горяева, Лапа, 2002, с. 200205 , рис. 1; Беспалый, Лукьяшко, 2008, с. 2123, табл. XIV,7].

В большинстве случаев мечи с серповидным навершием снабжены прямым брусковидным перекрестьем, мечи без перекрестья очень немногочисленны. А.С. Скрипкин, полагая, что часть мечей этого варианта все же имела несохранившиеся перекрестья, склонен датировать их в рамках всей раннесарматской культуры, включая и I в. до н.э. [Скрипкин, 1990, с. 119-120]. Однако не исключено, что мечи с серповидным наверши- 
ем без перекрестья поступали к донским сарматам из северо-кавказского региона, где традиция производства мечей с различными навершиями без перекрестья, восходящая к мечам «синдо-меотского» типа, существует достаточно долго [Смирнов, 1980, с. 43-44]. И.И. Марченко на кубанском материале определяет период бытования мечей с серповидным навершием без перекрестья в рамках второй четверти III - II в. до н.э. [Марченко, 1996, с. 50-51, рис. 12]. Такая относительно ранняя датировка косвенно подтверждается и донским материалом - в нижнедонской раннесарматской культуре все мечи этого варианта имеют клинки подтреугольной формы с равномерно сужающимися к острию лезвиями, что считается ранним хронологическим признаком [Глебов, 2007, с. 92-94].

Меч из погребения 24 (рис. 3,9). Мечи с кольцевидным навершием получают широкое распространение у сарматов со II в. до н.э. [Скрипкин, 2005, с. 181-184], хотя изредка встречаются уже в комплексах III в. до н.э. [Скрипкин, 2005, с. 183; Клепиков, 2007, с. 57]. Судя по неоднократным совместным находкам мечей с серповидными и кольцевидными навершиями [Скрипкин, 2014, с. 369373], какое-то время эти два типа мечей сосуществовали. Но постепенно кольцевидные навершия вытесняют серповидные. В I в. до н.э. мечи с кольцевидным навершием уже полностью преобладают и продолжают господствовать на протяжении всей последующей среднесарматской эпохи.

Следует отметить, что меч из погребения 24 не самого раннего облика - лезвия его клинка почти параллельны, заметно сужаются только у самого острия. У ранних образцов клинки обычно подтреугольной формы [Глебов, 2007, с. 94]. Однако на раннем этапе нижнедонской раннесарматской культуры мечи с кольцевидным навершием и почти параллельными лезвиями уже известны - например, Подгорненский IV, курган 7, погребение 3.

Наконечники стрел колчанного набора из погребения 17 (рис. 4,2). Наконечники с трехгранными или слабопрофилированными трехлопастными головками и длинными черешками считаются одной из наиболее ранних разновидностей черешковых наконечников стрел и появляются у сарматов в конце
IV или в III в. до н.э. [Хазанов, 1971, с. 36-37, Мошкова, 1963, с. 32; Скрипкин, 1990, с. 141; Клепиков, 2002, с. 46-47; Шинкарь, 2007, c. 110-111]. В Нижнем Подонье такие наконечники фиксируются в комплексах раннего этапа раннесарматской культуры II-I вв. до н.э., часто совстречаясь с другими вещами раннего облика: округлодонной посудой, зеркалами большого диаметра с валиком по краю диска и клиновидной ручкой, мечами с серповидным навершием и пр. [Глебов, 2007, с. 91$92 ; 2010$, с. 15-16]. Ранним признаком для черешковых наконечников можно считать четырехгранность черешков - почти все комплексы, содержащие наконечники стрел с четырехгранными черешками, относятся к раннему горизонту нижнедонской раннесарматской культуры [Глебов, 2007, с. 90-91].

Наконечники стрел колчанного набора из погребения 24 (рис. 3,5). Наконечники с трехлопастными головками высоких пропорций и средними или короткими черешками наиболее распространены в памятниках позднего этапа нижнедонской раннесарматской культуры [Глебов, 2007, с. 90-92]. На относительно раннюю хронологическую позицию наконечников из погребения 24 , возможно, указывает сводчатая форма их головок [Мошкова, 1963, с. 32; Хазанов, 1971, с. 36; Скрипкин, 1990, с. 141], однако трехлопастные наконечники со сводчатыми головками все же встречаются в погребениях раннесарматской культуры вплоть до самого ее финала, известны и в памятниках среднесарматского времени (могильник Новый).

Краснолаковый канфар из погребения 29А (рис. 6,1). Лаковая посуда в раннесарматских древностях Нижнего Подонья встречается достаточно редко, находки же канфаров вообще единичны. Помимо кулешовского известен еще только один экземпляр - чернолаковый канфар с росписью белой краской в виде гирлянды с зерновидными подвесками, найденный в кургане у хут. Веселый на Маныче [Артамонов, 1949, с. 315, рис. 19].

Техника орнамента в виде листьев, гирлянд, пальметт и т. п., выполненного жидкой глиной или краской поверх краснолакового или чернолакового покрытия по горлу или тулову сосуда, получившая название West Slope («Западный склон»), появилась в Аттике в первой 
половине III в. до н.э. (Rotroff, 1997, p. 38-43; Журавлев, 2015, с. 194). Несколько позже массовое изготовление разнообразной посуды, декорированной в стиле West Slope, в том числе и канфаров, начинается в Малой Азии (главным образом в Пергаме), Македонии и других неаттических центрах Средиземноморья, откуда такая посуда в качестве импортов попадает и в Северное Причерноморье (Книпович, 1949, с. 274-276; Забелина, 1992, с. 291294; Егорова, 2009, с. 46 и след., Журавлев, 2015, с. 194-200; и др.).

Согласно разработкам Т.В. Егоровой по типологии и хронологии лаковой посуды, производство кубков-канфаров с биконическим туловом может быть отнесено к первой четверти II в. до н.э. или к несколько более позднему времени [Егорова, 2009, с. 50].

«Мегарская» чаша из погребения 17 (рис. 4,6). Находки целых и фрагментированных «мегарских» чаш, как импортного производства, так и местных подражаний, весьма многочисленны в греческих и варварских городах и поселках Северного Причерноморья [Шелов, 1969, с. 220-247; Усачева, 1978, c. 100-107; Внуков, Коваленко, 1998, с. 61-76; Шкрибляк, 2012, с. 197-204; Шевченко, 2013, c. 20-21; и др.]. Однако в степь к сарматам такая посуда поступала в очень небольших количествах. В настоящее время в сарматских погребениях известно лишь несколько «мегарских» чаш - помимо кулешовской, это находки в курганах у хут. Элитный [Анфимов, 1986a, c. 194, рис. 3,2] и у ст-цы Новоджерелиевская [Анфимов, 19866 , с. 183 , рис. 1,1] на правобережье Кубани, в кургане могильника СевероЗападный І в низовьях Дона [Власкин, 2000, c. 10 , рис. 1,4], в кургане могильника Мариновка в междуречье Дона и Волги [Шинкарь, 2012, с. 192, рис. 1,2].

Судя по тесту и орнаментации, чаша из Кулешовки принадлежит к ионийской группе. Считается, что такая посуда производилась главным образом в Эфесе [Внуков, Коваленко, 1998, с. 62-66]. Исследования С.А. Коваленко показывают, что ввоз «мегарских» чаш из Ионийской Греции в Северное Причерноморье начался во второй четверти II в. до н.э., был наиболее интенсивным во второй половине столетия и резко снизился к концу II в. до н.э. [Коваленко, 2002, с. 82, 91-93]. В ма- териалах I в. до н.э. (преимущественно в первой половине столетия) находки «мегарских» чаш или их фрагментов известны, но в гораздо меньшем количестве [Кропотов, Лесков, 2006, с. 32-37; Шевченко, 2013, с. 20-21]. Вероятно, одной из наиболее поздних находок следует считать чашу из сарматского погребения в могильнике Северо-Западный I, найденную вместе с ранней лучковой фибулой [Власкин, 2000, с. 10, рис. 1,4].

Кувшин из погребения 29А (рис. 6,3) может быть отнесен к типу 2 по классификации Н.Ф. Шевченко - крупные кувшины с высоким яйцевидным туловом с выраженными плечиками и высоким цилиндрическим горлом - с датой конец III - первая половина II в. до н.э. [Шевченко, 1993, с. 33-34]. В отличие от парадной лаковой посуды, обычная столовая посуда боспорского производства (кувшины, миски, кружки) представлена в погребениях раннесарматской культуры очень широко.

Зеркала из погребений 10, 17, 29А,Б (рис. 3,$3 ; 4,3 ; 5,8,9$ ) принадлежат к двум основным типам зеркал раннесарматской культуры: 1) крупные зеркала с валиком по краю диска и клиновидной ручкой-штырем (зеркало из погребения 10 представлено фрагментом, поэтому нет полной уверенности в наличии у него ручки; однако все целые зеркала этого типа снабжены клиновидными ручками); 2) небольшие зеркала в виде плоского диска без ручки.

А.М. Хазанов и А.С. Скрипкин определяли основной период бытования зеркал большого диаметра с валиком по краю диска и клиновидной ручкой как III-I вв. до н.э. [Хазанов, 1963, с. 62-64, тип IV; Скрипкин, 1990, c. 150-151, тип 4.7]. По версии М.Г. Мошковой и Н.В. Рындиной, такие зеркала выходят из моды после II в. до н.э. [Мошкова, Рындина, 1975, с. 122]. Эту точку зрения следует признать верной - большие зеркала с валиком по краю диска и клиновидной ручкой-штырем преобладают в наиболее ранних памятниках нижнедонской раннесарматской культуры, датирующихся, видимо, II в. до н.э., позже находки таких зеркал становятся относительно редки, господствуют в это время уже другие формы - главным образом зеркала небольшого диаметра без валиков и ручек. 
Считается, что пик популярности зеркал в виде плоского диска небольшого диаметра без ручки у сарматов приходится на I в. до н.э. - I в. н.э., хотя появляются они гораздо раньше [Хазанов, 1963, с. 62-64, тип VI; Скрипкин, 1990, с. 143, тип 1.01, рис. 44]. Действительно, в Нижнем Подонье такие зеркала наиболее широко представлены в раннесарматских памятниках I в. до н.э. и на начальном этапе среднесарматской культуры. Тем не менее находки зеркал этого типа не так уж редки в комплексах II в. до н.э., известны и в памятниках IV - начала III в. до н.э.

Таким образом, большинство сарматских погребений из кургана 1 могильника Кулешовка относятся к раннему этапу нижнедонской раннесарматской культуры II-I вв. до н.э.: погребение 17 (меч с серповидным навершием, набор наконечников стрел раннего облика с длинными черешками, «мегарская» чаша), погребение 10 (фрагмент зеркала большого диаметра с валиком по краю диска), погребение 29 (краснолаковый канфар, боспорский кувшин). Вероятно, эта группа захоронений представляет собой семейно-родовой могильник. Время совершения этих погребений уточняется импортами: «мегарская» чаша из погребения 17 - вторая четверть - конец II в. до н.э., канфар из погребения 29A - в пределах первой половины II в. до н.э. Разрушенное погребение 9 не поддается узкой датировке, но очевидно, что оно было совершено раньше, чем нарушившее его погребение 10. Наиболее вероятной датой для всей группы погребений нам представляется вторая - третья четверть II в. до н.э.

Хронология погребения 10 не столь определенна - хотя мечи с кольцевидным навершием и наконечники стрел с короткими черешками известны и в ранних комплексах нижнедонской раннесарматской культуры, но массовое распространение они получают на более позднем ее этапе. Принадлежность этого погребения к группе сарматских захоронений раннего этапа в кургане 1 остается под вопросом. Не исключено, что погребение 10 крайнее западное в ряду раннесарматских захоронений - было впущено в курган позже (конец II - I в. до н.э.?) и не имеет с ними прямой связи. 


\section{ИЛЛЮСТРАЦИИ}

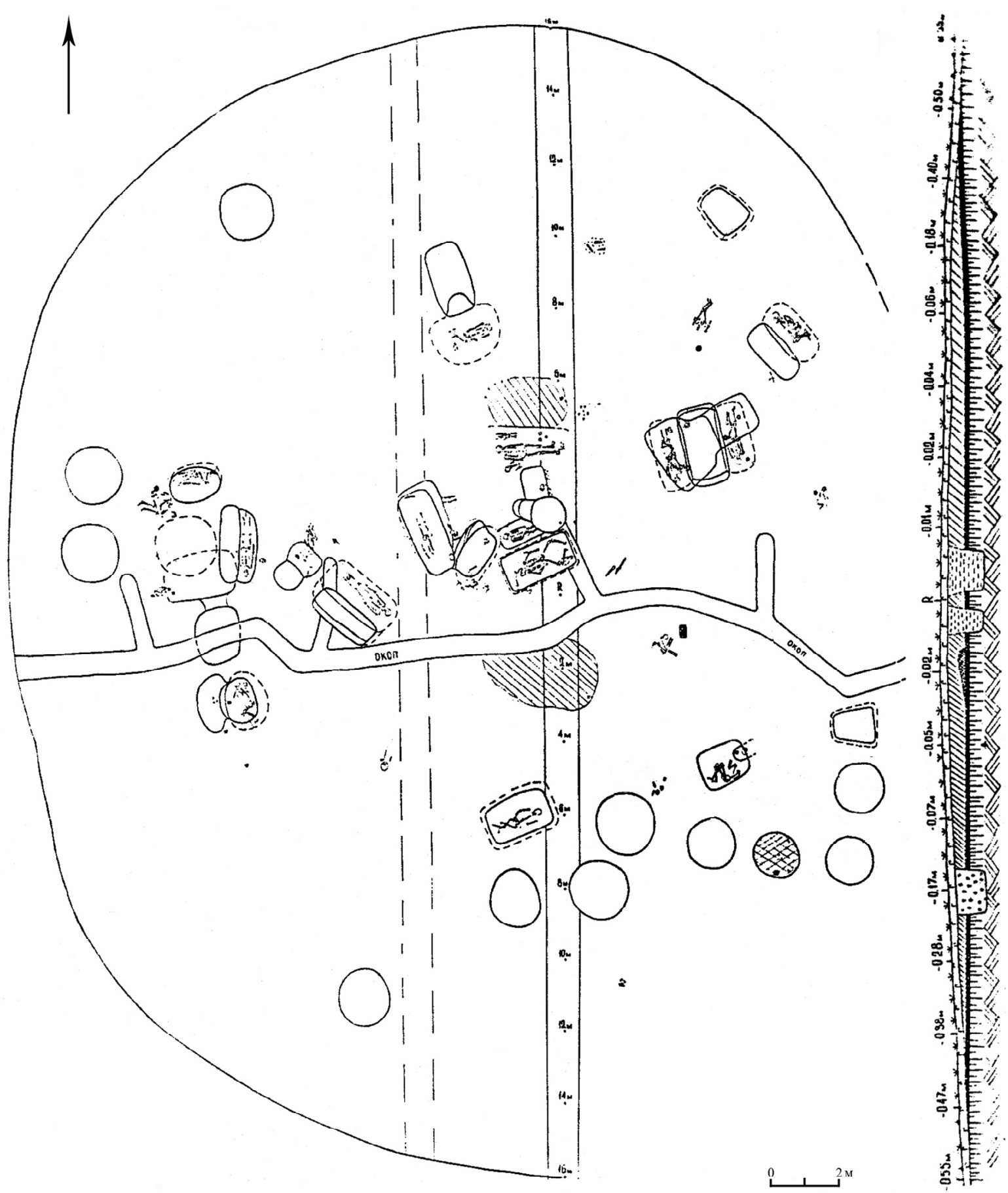

Рис. 1. План и профиль кургана 1 у с. Кулешовка

Fig. 1. Plan and profile of the burial mound 1 near the Kuleshovka village 

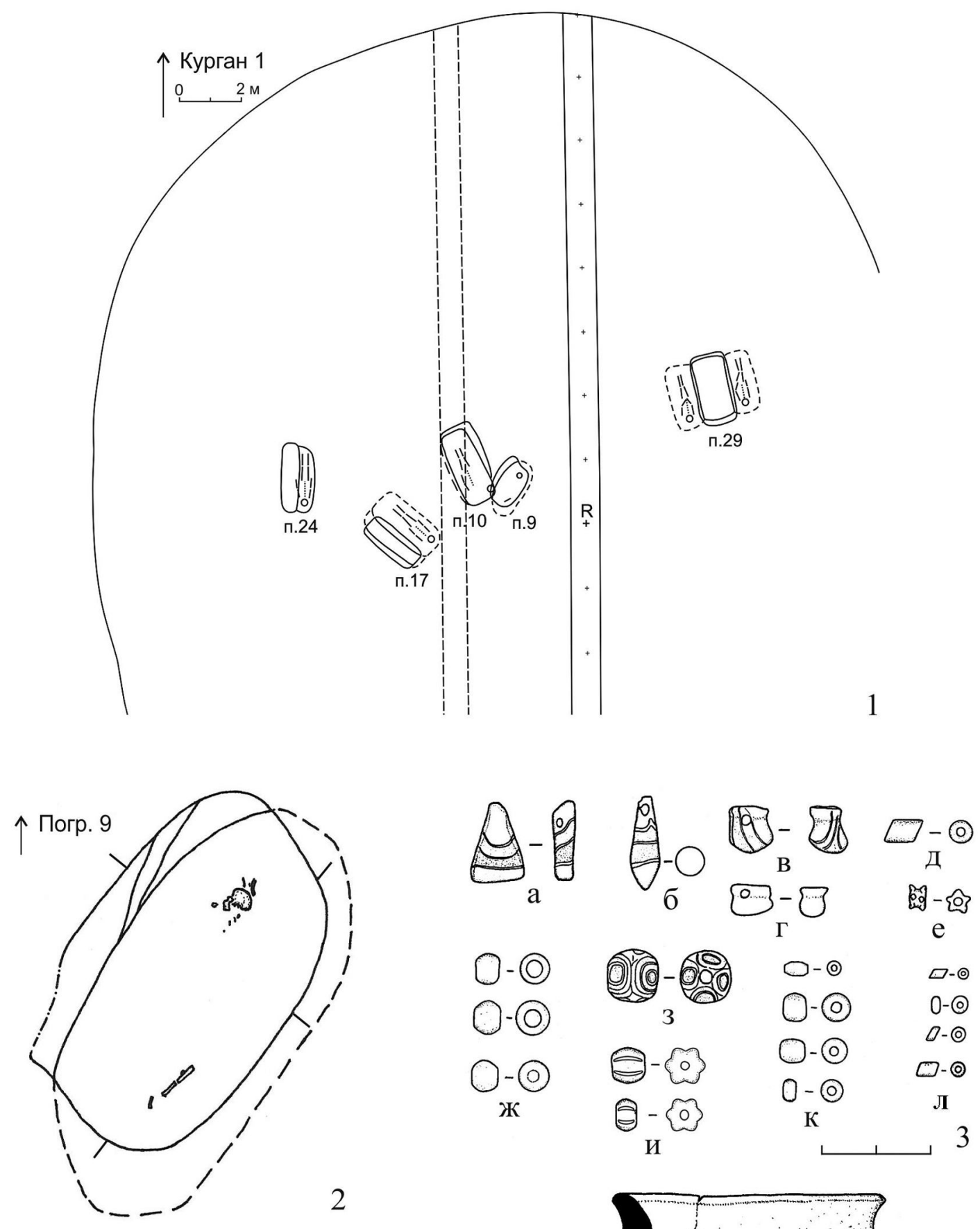

$\hat{\theta}-\hat{\theta}$

$\mathrm{e}$

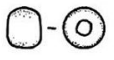

O-()

$0-(-)$
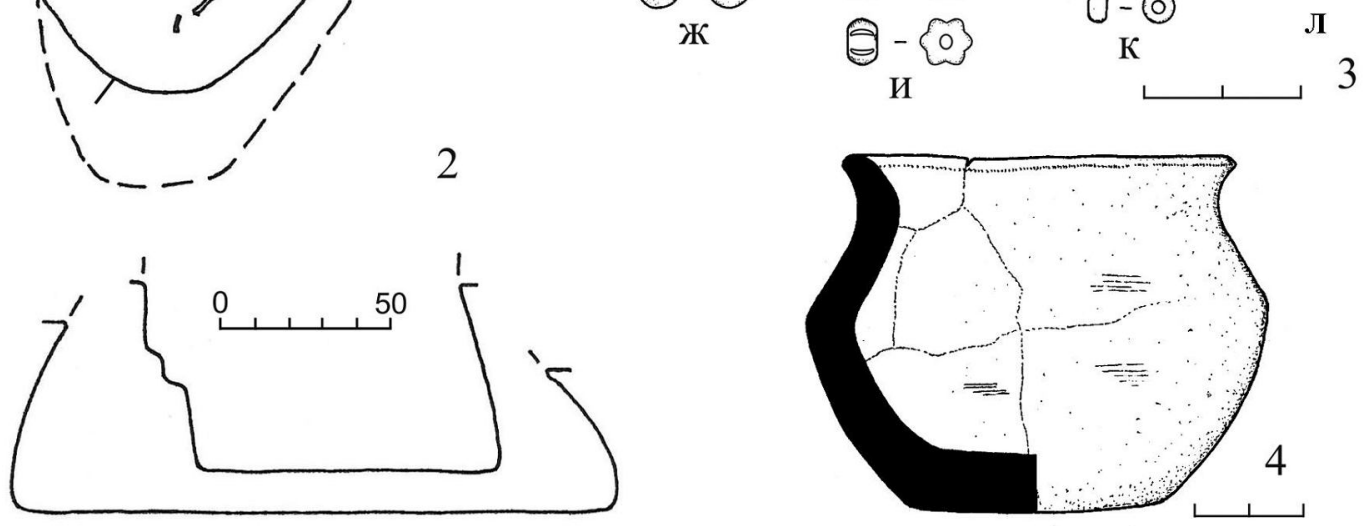

Рис. 2. 1 - расположение сарматских погребений в кургане $1 ; 2-4$ - погребение 9: 2 - план и профиль погребения; 3 - стеклянные бусы; 4 - лепной сосуд

Fig. 2. 1 - location of the Sarmatian burials in the burial mound 1;2-4-burial 9: 2 - plan and profile of burial; 3 - glass beads; 4 - stucco vessel 


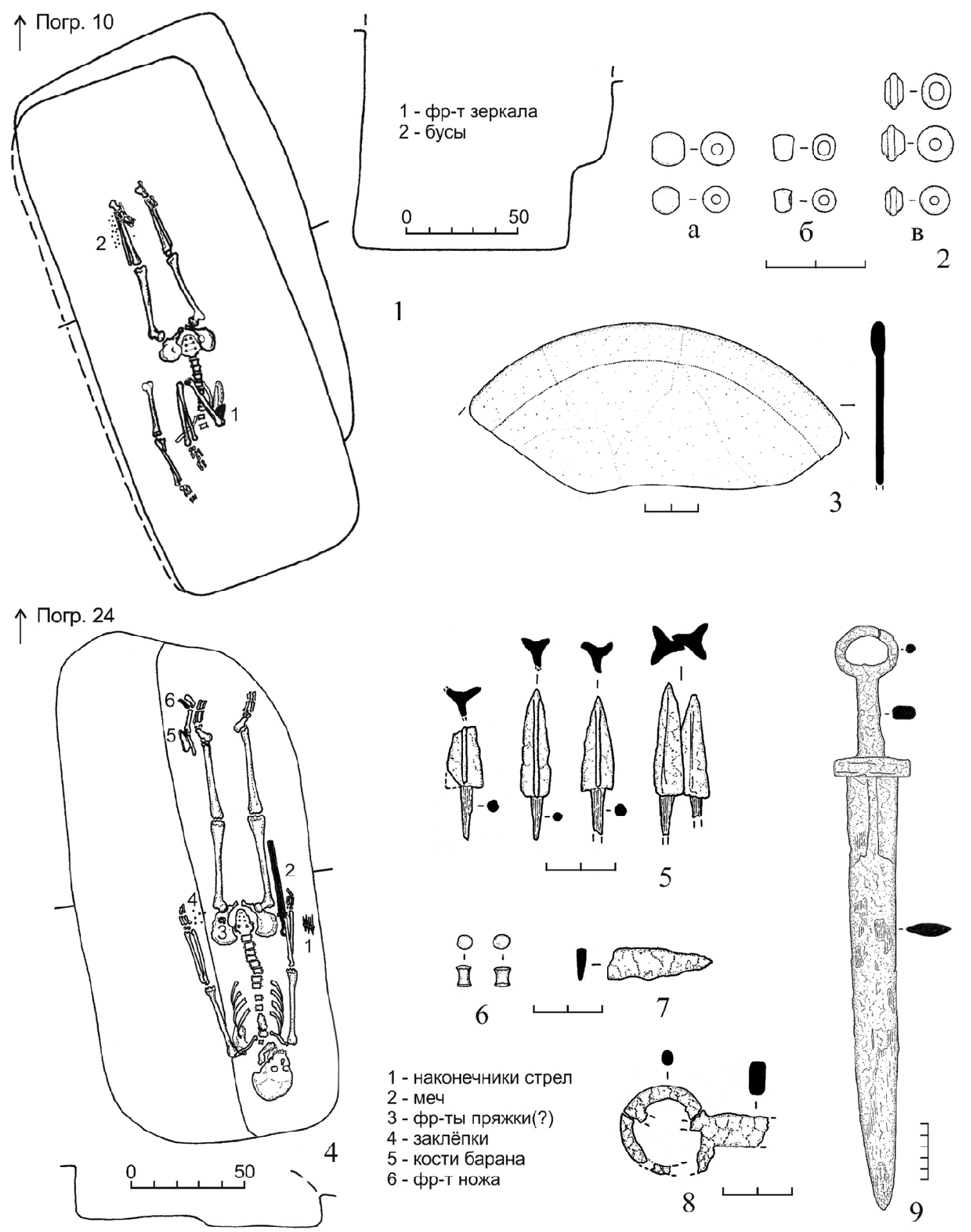

Рис. 3. 1-3 - погребение 10: 1 - план и профиль погребения; 2 - стеклянные бусы; 3 - фрагмент бронзового зеркала; 4-9 - погребение 24: 4 - план и профиль погребения; 5 - железные наконечники стрел; 6 - бронзовые заклепки; 7 - фрагмент железного ножа; 8 - фрагмент железного предмета; 9 - железный меч

Fig. 3. 1-3-burial 10: 1 - plan and profile of burial; 2 - glass beads; 3 - fragment of the bronze mirror; 4-9-burial 24: 4- plan and profile of burial; 5 - iron arrowheads; 6 - bronze rivets; 7 - fragment of an iron knife; 8 - fragment of an iron object; 9 - iron sword 




Рис. 4. 1-6- погребение 17: 1 - план и профиль погребения; 2 - железные наконечники стрел;

3 - фрагменты бронзового зеркала; 4 - костяная «проколка»; 5 - железный меч; 6 - «мегарская» чаша

Fig. 4. 1-6-burial 17: 1-plan and profile of burial; 2-iron arrowheads;

3 - fragments of bronze mirror; 4 - bone "punching"; 5 - iron sword; 6 - "Megarian" bowl 


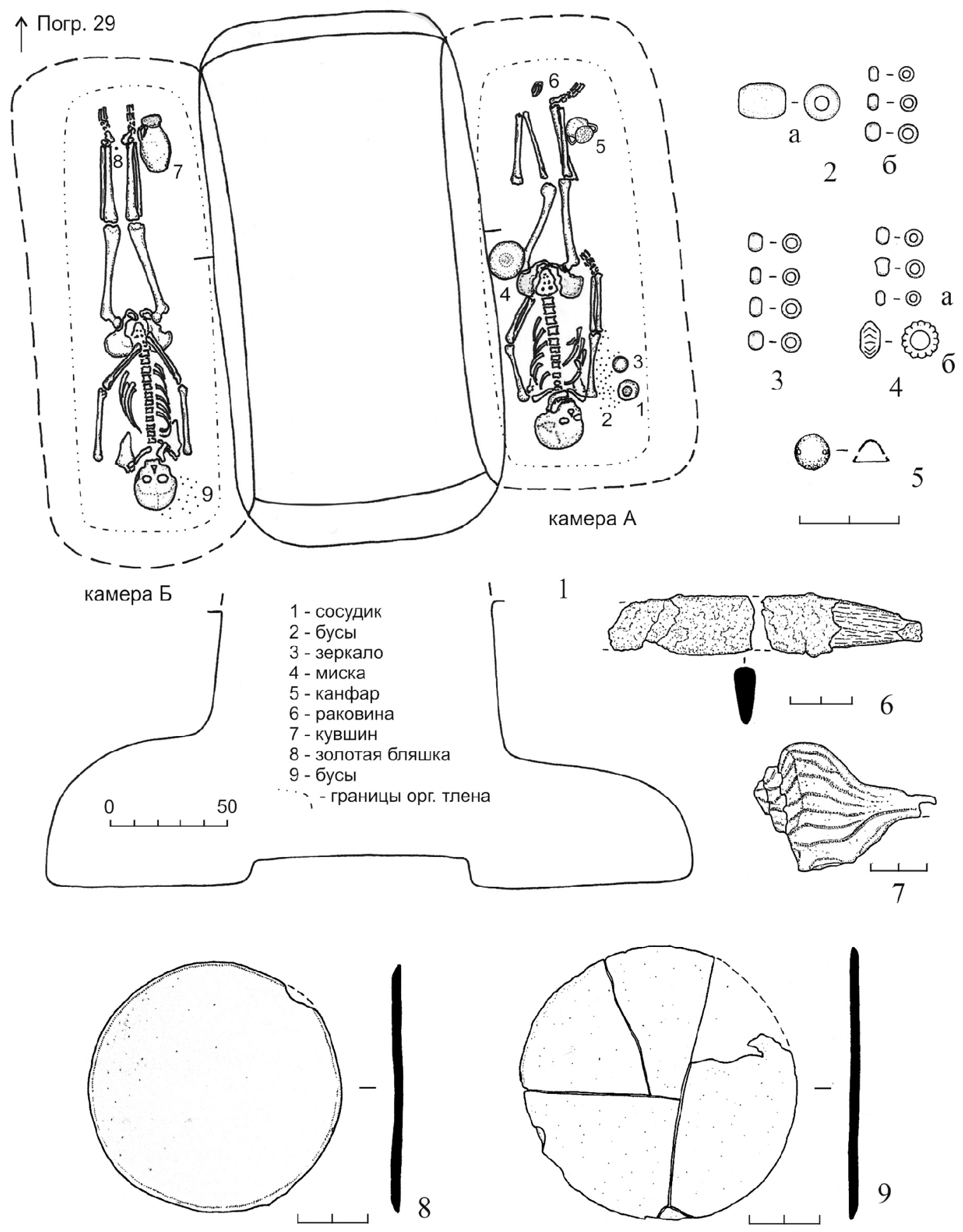

Рис. 5. 1-6 - погребение 29: 1 - план и профиль погребения; 2 - стеклянные бусы (заполнение колодца);

3 - стеклянные бусы (камера А); 4 - стеклянные бусы (камера Б); 5 - золотая бляшка (камера Б);

6 - фрагменты железного ножа (камера Б); 7 - раковина (камера А); 8 - бронзовое зеркало (камера А); 9 - бронзовое зеркало (камера Б)

Fig. 5. 1-6-burial 29: 1-plan and profile of burial; 2-glass beads (filling the grave);

3 - glass beads (chamber A); 4 - glass beads (chamber B); 5 - gold plaque (chamber B);

6 - fragments of an iron knife (chamber B); 7 - sink (chamber A); 8 - bronze mirror (chamber A); 9 - bronze mirror (chamber B) 


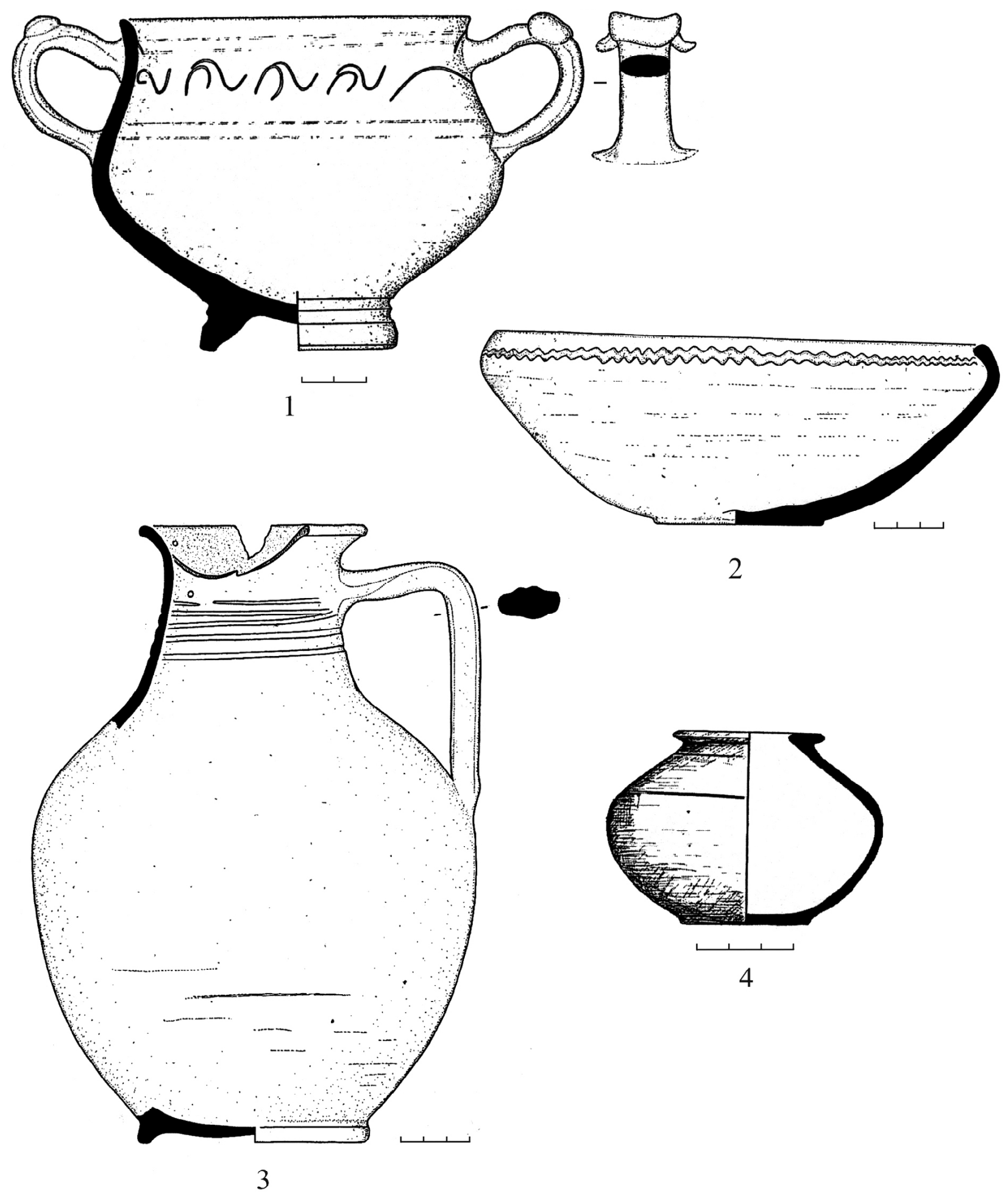

Рис. 6. 1-4 - погребение 29: 1 - краснолаковый канфар (камера А); 2 - оранжевоглиняная миска (камера А); 3 - оранжевоглиняный кувшин (камера Б); 4 - кружальный (?) сосу дик (камера А)

Fig. 6. 1-4-burial 29: 1-red-lacquer kanfar (chamber A); 2 - orange-clay bowl (chamber A); 3 - orange-clay jug (chamber B); 4 - pottery (?) vessel (chamber A) 


\section{ПРИМЕЧАНИЯ}

1 За центральный репер $\left(R_{0}\right)$ была принята вершина кургана.

${ }^{2}$ Половозрастные определения, приведенные в отчете о раскопках, были сделаны Е.И. Беспалым в полевых условиях. Позже с костным материалом из некоторых погребений этого кургана работали профессиональные антропологи - Е.Ф. Батиева и М.А. Балабанова, их определения, в большинстве случаев совпадающие с определениями Е.И. Беспалого, приведены в настоящей статье. Пользуясь случаем, выражаю благодарность Е.Ф. Батиевой за информацию об антропологических определениях, не попавших в отчет.

${ }^{3}$ Относительно пола и возраста погребенного из погребения 17 в определениях имеются разногласия: согласно полевым определениям Е.И. Беспалого это взрослая женщина, по Е.Ф. Батиевой женщина 35-40 лет, по М.А. Балабановой - мужчина 50-60 лет.

${ }^{4}$ На плане погребения отмечено бо́льшее количество заклепок - не менее шести. Вероятно, не все из них сохранились.

\section{СПИСОК ЛИТЕРАТУРЫ}

Анфимов И. Н., 1986а. Погребальный комплекс II в. до н.э. у хут. Элитный (Краснодарский край) // Новое в археологии Северного Кавказа : сб. науч. ст. М. : Наука. С. 190-197.

Анфимов Н. В., 1986б. Курганный комплекс сарматского времени из бассейна р. Кирпили // Новое в археологии Северного Кавказа : сб. науч. ст. М. : Наука. С. 183-190.

Артамонов М. И., 1949. Раскопки курганов на p. Маныч // Советская археология. Вып. XI. C. 305-336.

Беспалый Е. И., Лукьяшко С. И., 2008. Древнее население междуречья Дона и Кагальника. Курганный могильник у с. Высочино. Т. 1. Ростов н/Д : Изд-во ЮНЦ РАН. 224 с.

Васильев В. Н., 2001. Вооружение и военное дело кочевников Южного Урала в VI-II вв. до н.э. Уфа: Гилем. 154 с.

Власкин М. В., 2000. Раннесарматские погребения могильника Северо-Западный I // Сарматы и их соседи на Дону. Материалы и исследования по археологии Дона : сб. науч. ст. Вып. 1. Ростов н/Д : Терра. С. 9-26.

Внуков С. Ю., Коваленко С. А., 1998. Мегарские чаши с городища Кара-Тобе // Эллинистическая и римская керамика в Северном Причерноморье. Труды ГИМ : сб. науч. ст. Вып. 102. М. : Изд-во Гос. ист. музея. С. 61-76.
Глебов В. П., 2007. Вооружение и военное дело кочевников Нижнего Подонья раннесарматского времени // Вооружение сарматов. Региональная типология и хронология : докл. к VI Междунар. конф. «Проблемы сарматской археологии и истории». Челябинск : Изд-во ЮУрГУ. С. 88-98.

Глебов В. П., 2010. Раннесарматская культура Нижнего Подонья II-I вв. до н.э. : автореф. дис. ... канд. ист. наук. М. 26 с.

Глебов В. П., 2011. Погребальная обрядность раннесарматской культуры Нижнего Подонья III вв. до н.э. // Погребальный обряд ранних кочевников Евразии : материалы VII Междунар. науч. конф. «Проблемы сарматской археологии и истории». Ростов н/Д : Изд-во ЮНЦРАН. С. $34-48$.

Егорова Т. В., 2009. Чернолаковая керамика IV-II вв. до н.э. с памятников Северо-Западного Крыма. М. : Изд-во МГУ. 253 с.

Железчиков Б. Ф., Клепиков В. М., Сергацков И. В., 2006. Древности Лебедевки (VI-II вв. до н.э.). М. : Вост. лит. 159 с.

Журавлев Д. В., 2015. Пергамская эллинистическая столовая посуда в Северном Причерноморье (краткий обзор) // Проблемы истории, филологии, культуры. № 1 (47). С. 190-216.

Забелина В. С., 1992. Расписная керамика эллинистического времени из раскопок Пантикапея 19451974 гг. // Сообщения Государственного музея изобразительных искусств им. А.С. Пушкина : сб. науч. ст. Вып. 10. М. : Советский художник, C. $284-297$.

Клепиков В. М., 2002. Сарматы Нижнего Поволжья в IV-III вв. до н.э. Волгоград: Изд-во ВолГУ. 216 с.

Клепиков В. М., 2007. Раннесарматские мечи в Нижнем Поволжье // Вооружение сарматов. Региональная типология и хронология : докл. к VI Междунар. конф. «Проблемы сарматской археологии и истории». Челябинск : Изд-во ЮУрГУ. С. 51-57.

Книпович Т. Н., 1949. К вопросу о торговых сношениях античных колоний Северного Причерноморья в эпоху эллинизма // Советская археология. Вып. ХІ. С. 271-284.

Коваленко С. А., 2002. О структуре и динамике импорта позднеэллинистической рельефной керамики в Северное Причерноморье // Археологія. №3. C. 80-96.

Кропотов В. В., Лесков А. М., 2006. Курган с «коллективным погребением» у с. Кринички (по материалам работ 1957 г.) // Культура народов Причерноморья. № 84. Симферополь : Межвузовский центр «Крым». С. 25-39.

Марченко И. И., 1996. Сираки Кубани. Краснодар : Изд-во КубГУ. 340 с. 
Мордвинцева В. И., 1993. К проблеме семейно-родовых отношений у сарматов (по материалам сарматских погребений последних веков до н.э.) // Вопросы краеведения. Материалы краеведческих чтений : сб. науч. ст. Вып. 2. Волгоград : Изд-во ВолГУ. С. 31-34.

Мошкова М. Г., 1963. Памятники прохоровской культуры. М. : Изд-во АН СССР. 56 с.

Мошкова М. Г., Рындина Н. В., 1975. Сарматские зеркала Поволжья и Приуралья (химико-технологический анализ) // Очерки технологии древнейших производств : сб. науч. ст. М. : Наука. С. 117-133.

Очир-Горяева М. А., Лапа Н. Л., 2002. Комплекс сарматского воинского погребения из фондов Калмыцкого республиканского краеведческого музея // Вестник древней истории. № 3. C. 200-205.

Сергацков И. В., 1995. Новые данные к хронологии раннесарматской культуры // Российская археология. № 1. С. 148-157.

Сергацков И. В., 2000. Сарматские курганы на Иловле. Волгоград : Изд-во ВолГУ. 396 с.

Скрипкин А. С., 1990. Азиатская Сарматия. Проблемы хронологии и ее исторический аспект. Саратов : Изд-во СГУ. 300 с.

Скрипкин А. С., 2005. Сарматские мечи с кольцевидным навершием // II Городцовские чтения. Материалы научной конференции, посвященной 100-летию деятельности В.А. Городцова в ГИМ. Тр. ГИМ: сб. науч. ст. Вып. 145. М. : Изд-во Гос. ист. музея. С. 171-185.

Скрипкин А. С., 2014. Клинковое оружие в разработке хронологии и некоторых вопросов этнополитической истории раннесарматской культуры Волго-Уральского региона // Война и военное дело в скифо-сарматском мире : материалы Междунар. науч. конф., посвящ. памяти А.И. Мелюковой. Ростов н/Д : Изд-во ЮНЦРАН. С. 367-379.

Смирнов К. Ф., 1960. Быковские курганы // Древности Нижнего Поволжья : (Итоги работ Сталинградской археологической экспедиции). Материалы и исследования по археологии СССР. № 78. М. : Изд-во АН СССР. С. 167-268.

Смирнов К. Ф., 1961. Вооружение савроматов // Материалы и исследования по археологии СССР. № 101. М. : Изд-во АН СССР. 162 с.

Смирнов К. Ф., 1980. О мечах синдо-меотского типа // Краткие сообщения Института Археологии. № 162. С. $38-45$.

Усачева О. Н., 1978. Рельефная керамика из Кеп // Краткие сообщения Института Археологии. № 156. C. $100-107$.

Хазанов А. М., 1963. Генезис сарматских бронзовых зеркал // Советская археология. № 4. С. 58-71.
Хазанов А. М., 1971. Очерки военного дела сарматов. М. : Наука. 172 с.

Шевченко Н. Ф., 1993. Некоторые аспекты боспоро-сарматских отношений в Восточном Приазовье (III в. до н.э - II в. н.э) // Музейный вестник : сб. науч. ст. Вып. 1. Краснодар : КГИАМЗ. С. 31-44.

Шевченко Н. Ф., 2013. Племена Восточного Приазовья на рубеже эры. Ростов н/Д : Альтаир. $152 \mathrm{c}$.

Шелов Д. Б., 1969. Находки в Танаисе «мегарских» чаш // Античные древности Подонья - Приазовья. Материалы и исследования по археологии СССР. № 154. М. : Изд-во АН СССР. С. 220-247.

Шинкарь О. А., 2007. Типология и хронология раннесарматских наконечников стрел по материалам Нижнего Поволжья // Вопросы истории и археологии Западного Казахстана. № 1. С. 103-119.

Шинкарь О. А., 2012. Северопричерноморские импортные изделия в погребениях III-II вв. до н.э. Волго-Донского междуречья // Древности Северного Причерноморья III-II вв. до н.э. : материалы Междунар. науч. конф. Тирасполь : Изд-во Приднестр. гос. ун-та. С. 192-196.

Шкрибляк И. И., 2012. Мегарские чаши из раскопок Неаполя Скифского (предварительный анализ) // Древности Северного Причерноморья III-II вв. до н.э. : материалы Междунар. науч. конф. Тирасполь : Изд-во Приднестр. гос. унта. C. 197-205.

Rotroff S. I., 1997. Hellenistic pottery. Athenian and imported wheelmade table ware and related material // The Athenian Agora. Vol. XXXIX. Princeton. 575 p.

\section{REFERENCES}

Anfimov I.N., 1986a. The burial complex of the $2^{\text {nd }}$ century $\mathrm{BC}$ in the Elitny village (Krasnodar region). The new in the archaeology of the North Caucasus: collected scientific articles. Moscow, Nauka Publ., pp. 190-197. (in Russian).

Anfimov N.V., 1986b. Barrow complex of the Sarmatian time from the basin of the Kirpili river. The new in the archaeology of the North Caucasus: collected scientific articles. Moscow, Nauka Publ., pp. 183-190. (in Russian).

Artamonov M.I., 1949. Excavations of mounds on the Manych river. Soviet archaeology, iss. XI, pp. 305-336. (in Russian).

Bespalyy E.I., Lukyashko S.I., 2008. Ancient population of the interfluve of the Don and Kagalnik. Burial mound near village Vysochino, vol. 1. Rostov-on-Don, Izd-vo UNTs RAN. 224 p. (in Russian). 
Vasilyev V.N., 2001. Arms and military business of nomads of the Southern Ural in the $6^{\text {th }}-2^{\text {nd }}$ centuries BC. Ufa, Gilem Publ. 154 p. (in Russian).

Vlaskin M.V., 2000. Early Sarmatian burials of the Severo-Zapadny I burial mound. Sarmatians and their neighbors on the Don. Materials and research on the archaeology of the Don: collected scientific articles, iss. 1. Rostov-onDon, Terra Publ., pp. 9-26. (in Russian).

Vnukov S.Yu., Kovalenko S.A., 1998. Megarian bowls from the Kara-Tobe fortress. Hellenistic and Roman ceramics in the Northern Black Sea Coast. Transactions of GIM: collected scientific articles, iss. 102. Moscow, Izd-vo Gos. ist. muzeya, pp. 61-76. (in Russian).

Glebov V.P., 2007. Arms and military business of the nomads of the Lower Don region of the Early Sarmatian time. Arms of the Sarmatians. Regional typology and chronology: reports of the $6^{\text {th }}$ International Conference "Problems of Sarmatian archaeology and history”. Chelyabinsk, Izd-vo IuUrGU, pp. 88-98. (in Russian).

Glebov V.P., 2010. Early Sarmatian culture of the Lower Donets of the $2^{\text {nd }}-1^{\text {st }}$ centuries BC. Cand. hist. sci. abs. diss. Moscow. 26 p. (in Russian).

Glebov V.P., 2011. Funeral rite of the Early Sarmatian culture of the Lower Don region of the $2^{\text {nd }}-1^{\text {st }}$ centuries BC. Funeral rite of the Early Sarmatian culture of the Lower Donets of the $2^{\text {nd }}-1^{\text {st }} c c$. BC. Rostov-onDon, Izd-vo YUNTS RAN, pp. 34-48. (in Russian).

Egorova T.V., 2009. Black-lacquered ceramics of the $4^{\text {th }}-2^{\text {nd }}$ centuries BC from the monuments of the North-Western Crimea. Moscow, Izd-vo MGU. 253 p. (in Russian).

Zhelezchikov B.F., Klepikov V.M., Sergatskov I.V., 2006. Antiquities of the Lebedovka $\left(4^{\text {th }}-2^{\text {nd }}\right.$ centuries $B C)$. Moscow, Vostochnaya literatura Publ. 159 p. (in Russian).

Zhuravlev D.V., 2015. Hellenistic Pergamene table ware in the North Pontic (short review). Problems of history, philology, culture, no. 1 (47), pp. 190216. (in Russian).

Zabelina V.S., 1992. Painted ceramics of Hellenistic time from excavations of Panticapaeum 1945-1974. News of the State Museum of Fine Arts named after A.S. Pushkin: collected scientific articles, iss. 10. Moscow, Sovetskiy khudozhnik Publ., pp. 284-297. (in Russian).

Klepikov V.M., 2002. Sarmatians of the Lower Volga region in the $4^{\text {th }}-3^{\text {rd }}$ centuries $B C$. Volgograd, Izd-vo VolGU. 216 p. (in Russian).

Klepikov V.M., 2007. Early Sarmatian swords in the Lower Volga region. Arms of the Sarmatians. Regional typology and chronology: reports to the $6^{\text {th }}$ International conference "Problems of Sarmatian archaeology and history".
Chelyabinsk, Izd-vo IuUrGU, pp. 51-57. (in Russian).

Knipovich T.N., 1949. On the question of trade relations of the ancient colonies of the Northern Black Sea Region in the Hellenistic period. Soviet archaeology, iss. XI, pp. 271-284. (in Russian).

Kovalenko S.A., 2002. About structure and dynamics of the import of Late Hellenistic relief pottery in the North Pontic region. Archaeology, no. 3, pp. 80-96. (in Russian).

Kropotov V.V., Leskov A.M., 2006. The burial mound with "collective burial" near Krynichki village (based on the works of 1957). Culture of the peoples of the Black Sea region. no. 84 . Simferopol, Mezhvuzovskiy tsentr "Krym", pp. 25-39.

Marchenko I.I., 1996. Shiraki of the Kuban. Krasnodar, Izd-vo KubGU. 340 p. (in Russian).

Mordvintseva V.I., 1993. On the problem of family-clan relations in the Sarmatians (based on the materials of the Sarmatian burials of the last centuries BC). Questions of local history. Materials of local lore readings: collected scientific articles, iss. 2. Volgograd, Izd-vo VolGU, pp. 31-34. (in Russian).

Moshkova M.G., 1963. Monuments of Prokhorov culture. Moscow, Izd-vo AN SSSR. 56 p. (in Russian).

Moshkova M.G., Ryndina N.V., 1975. Sarmatian mirrors of the Volga and the Urals regions (chemical and technological analysis). Essays on the technology of the oldest productions: collected scientific articles. Moscow, Nauka Publ., pp. 117-133. (in Russian).

Ochir-Goryaeva M.A., Lapa N.L., 2002. Complex of the Sarmatian military burial from the funds of the Kalmyk Republican Museum of Local History. Vestnik drevney istorii, no. 3, pp. 200-205. (in Russian).

Sergatskov I.V., 1995. New data to the chronology of the Early Sarmatian culture. Russian archaeology, no. 1, pp. 148-157. (in Russian).

Sergatskov I.V., 2000. Sarmatian burial mounds on Ilovlya river. Volgograd, Izd-vo VolGU. 396 p. (in Russian).

Skripkin A.S., 1990. Asian Sarmatia. Problems of chronology and its historical aspect. Saratov, Izd-vo SGU. 300 p. (in Russian).

Skripkin A.S., 2005. Sarmatian swords with ring-shaped head. The $2^{\text {nd }}$ II Gorodtsov readings. Proceedings of the scientific conference, devoted to the $100^{\text {th }}$ anniversary of V.A. Gorodtsov's activity in GIM. Works of GIM: collected scientific articles, iss. 145. Moscow, Izd-vo Gos. ist. muzeya, pp. 171-185. (in Russian).

Skripkin A.S., 2014. Blade weapons in the development of chronology and some issues of the 
ethnopolitical history of the Early Sarmatian culture of the Volga-Ural region. War and military affairs in the Scythian-Sarmatian world: proceedings of the International scientific conference in memory of A.I. Melyukova. Rostov-na-Donu, Izd-vo YUNTs RAN, pp. 367-379. (in Russian).

Smirnov K.F., 1960. Bykovsky burial mounds. Antiquities of the Lower Volga region: (results of the work of the Stalingrad archaeological expedition). Materials and research on archaeology of the USSR, no. 78. Moscow, Izdvo AN SSSR, pp. 167-268. (in Russian).

Smirnov K.F., 1961. Armament of the Sauromats. Materials and research on archaeology of the USSR, no. 101. Moscow, Izd-vo AN SSSR. 162 p. (in Russian).

Smirnov K.F., 1980. About swords of the SindoMeotian type. Brief news of the Institute of archaeology, no. 162, pp. 38-45. (in Russian).

Usacheva O.N., 1978. Relief ceramics from Kepi. Brief news of the Institute of archaeology, no. 156, pp. 100-107. (in Russian).

Khazanov A.M., 1963. Genesis of Sarmatian bronze mirrors. Soviet archaeology, no. 4, pp. 58-71. (in Russian).

Khazanov A.M., 1971. Essays on the military affairs of the Sarmatians. Moscow, Nauka Publ. 172 p. (in Russian).

Shevchenko N.F., 1993. Some aspects of BosporoSarmatian relations in the Eastern Priazovye ( $3^{\text {rd }}$ century $\mathrm{BC}-2^{\text {nd }}$ century $\left.\mathrm{AD}\right)$. Museum bulletin: collected scientific articles, iss. 1. Krasnodar, Izd-vo KGIAMZ, pp. 31-44. (in Russian).

Shevchenko N.F., 2013. Tribes of the Eastern Azov region at the turn of the era. Rostov-on-Don, Altair Publ. 152 p. (in Russian).

Shelov D.B., 1969. Finds in Tanais "Megarian" bowls. Antiquities of the Donets-Azov Sea. Materials and research on archaeology of the USSR, no. 154. Moscow, Izd-voANSSSR, pp. 220-247. (in Russian).

Shinkar O.A., 2007. Typology and chronology of the Early Sarmatian arrowheads on the materials of the Lower Volga Region. Issues of History and Archaeology of Western Kazakhstan, no. 1, pp. 103-119. (in Russian).

Shinkar O.A., 2012. The North Pontic import products in the burials of the III-II centuries BC the VolgaDon interfluves. Antiquities of the Northern Black Sea region in the $3^{\text {rd }}-2^{\text {nd }}$ centuries $B C$ : Proceedings of International scientific conference. Tiraspol, Izd-vo Pridnestr. gos. unta, pp. 192-196. (in Russian).

Shkriblyak I.I., 2012. Megarian bowls from the excavations of Neapol Scythian (preliminary analysis). Antiquities of the Northern Black Sea region in the $3^{\text {rd }}-2^{\text {nd }}$ centuries $B C$ : Proceedings of International scientific conference. Tiraspol, Izd-vo Pridnestr. gos. un-ta, pp. 197-205. (in Russian).

Rotroff S.I., 1997. Hellenistic pottery. Athenian and imported wheelmade table ware and related material. The Athenian Agora, vol. XXXIX. Princeton. 575 p.

\section{Information About the Author}

Vyacheslav P. Glebov, Candidate of Sciences (History), Researcher, Archaeological Research Bureau, Ulyanovskaya St., 50, 344002 Rostov-on-Don, Russian Federation, glebov-63@mail.ru.

\section{Информация об авторе}

Вячеслав Петрович Глебов, кандидат исторических наук, научный сотрудник, Археологическое научно-исследовательское бюро, ул. Ульяновская, 50, 344002 г. Ростов-на-Дону, Российская Федерация, glebov-63@mail.ru. 